\title{
Patient in Body Sling
}

National Cancer Institute

\section{Source}

National Cancer Institute. Patient in Body Sling. NCI Thesaurus. Code C92604.

A position in which the subject's body is supported by a sling. 